\title{
Customary Law and Authority in a State under Construction: The Case of South Sudan
}

\author{
Jan Arno Hessbruegge* \\ Human Rights Officer, Office of the United Nations High Commissioner for Human Rights, \\ United Nations Office at Geneva, CH-1211 Geneva, Switzerland
}

\begin{abstract}
Customary law in South Sudan is a powerful symbol of emancipation from two centuries of external domination, and paradoxically, also the product of such external domination. Most citizens of the world's newest state rely more on customary laws and local authorities to regulate their conflicts than on other civilian state institutions and statutory law. At the current juncture, influential decision-makers in and outside the government are pushing to develop Sudan's customary laws into a Common Law for South Sudan. However, the legacy of the armed conflict, including patterns of militarization, and the ongoing modernization of society, pose challenges for customary systems. Furthermore, customary systems exhibit certain human rights deficits and, therefore, need to be made compatible with the constitutional framework of South Sudan. The recognition of customary authority and law as an essential part of the governance structure, coupled with targeted engagement and reform, are indispensable elements of state and peace building in South Sudan. The government and its external partners must walk a tightrope to integrate the local capacity offered by the customary system into their wider efforts without inadvertently stifling its potential to reform from within or undermining democratically elected institutions.
\end{abstract}

\section{Keywords}

South Sudan, customary authority, customary law, customary system, common law, development, governance structure

\section{Introduction}

On 14 July 2011 South Sudan became the 193rd member state of the United Nations. This marks the latest chapter in a troubled history that features two centuries of external domination and internal armed conflicts that lasted the better part of Sudan's half-century of post-colonial history. The new U.N. member state is not yet much of a State in the Weberian sense. Outside the urban centers, it hardly exists as a force of order in the lives of most citizens. Instead, they rely

* E-mail: jhessbruegge@ohchr.org. Jan Arno Hessbruegge (MALD, The Fletcher School of Law and Diplomacy; First Legal State Examination, University of Münster; Diploma in Public International Law; Hague Academy International Law) works for the Rule of Law and Democracy Section of the Office of the United Nations High Commissioner for Human Rights. The article is submitted in a personal capacity and the views expressed do not necessarily represent those of the United Nations. 
on customary law (i.e., practices that are accepted to derive from binding rules by the respective community following them) and customary authorities to regulate their conflicts and local affairs. ${ }^{1}$ Observers estimate that nine out of every ten conflicts are resolved on the basis of customary law. ${ }^{2}$ Customary law and authority defines the identity of South Sudan and its society more than the elected civilian institutions of government.

This article argues that the recognition of customary authority and law as an essential part of the governance structure, coupled with targeted engagement and reform, are indispensable elements of state- and peacebuilding in South Sudan, bearing in mind the country's history, socio-cultural identity and the foreseeable weakness of civilian central state institutions for years to come. The Government and its external assistance partners must walk a tightrope of integrating the local capacity offered by the customary system into their wider state- and peacebuilding efforts, without inadvertently stifling its potential to reform from within or undermining the potential of democratically elected and accountable civilian institutions to expand their legitimacy and reach.

\section{The Legitimacy of Customary Law and Authority}

Policymakers have often approached the potential role in customary law and authority in post-conflict societies through an oversimplified cost-benefits analysis. The accessibility and cost effectiveness of the customary system, as a temporary stop-gap measure, is weighed against its shortcomings in terms of human rights and democratic accountability, before "deciding" on the role for customary law in the short to medium term. For one, this overestimates the capacity and legitimacy of weak post-conflict states to impose any institutional choices on local communities. More importantly, it misses the larger issue of custom being a marker of identity that can reinforce or tear apart the State to be built.

\footnotetext{
1) The definition of customary law used for purposes of this article draws on the definition of customary law in the sphere of international law. See in this regard Statute of the International Court of Justice, article $38(1)$ (c). For a more detailed discussion on how customary law and mere social practices can be distinguished, see Brian Z. Tamanaha, 'Understanding Legal Pluralism: Past to Present, Local to Global', (2008) 30 Sydney Law Review 375-411, at 391-396. Even though customary law often derives legitimacy from its claim to represent an immutable tradition since time immemorial, any customary legal order is a dynamic body of law that lives from and evolves through the constant reaffirmation of the binding nature of its rules by the community living in accordance with the practice these rules are grounded in. It is neither suggested that customary law necessarily stands only outside the realm of law that is recognized by the State as such. In South Sudan in particular, customary law forms part of State law, where it exists alongside non-customary legal rules that emanate directly from statutes and executive decrees.

2) Aleu Akechak Jok, Robert A. Leitch and Carrie Vandewint, A Study of Customary Law in Contemporary Southern Sudan (World Vision International and The South Sudan Secretariat of Legal and Constitutional Affairs, New York, NY, 2004) 6.
} 
In recent years, academics from a variety of disciplines have taken a greater interest in the issue and have initiated a debate on the role of customary law and institutions in resolving conflict at the micro- and macro-levels and contributing to building peace that increasingly reverberates also in the policy arena. The academic literature approaches the subject from three angles that all have a bearing on the legitimacy of promoting, or at least accepting, customary law and authority as desirable elements of post-conflict governance:

- The historical pedigree of customary law as an indigenous tradition;

- The efficacy of the customary system, as it stands today, to resolve conflict at the micro- and macro-level; and

- Its compliance with international standards, in particular the principle of gender equality and other human rights norms.

In the eyes of the local population, customary law and authority derives much of its legitimacy from the claim of representing indigenous traditions that have been followed since time immemorial and thus predate foreign colonial impositions. Older anthropological studies of "native" law largely reaffirmed this myth. ${ }^{3}$ However, starting in the 1980s, anthropological research, conducted in particular in Africa, revealed how customary law, as it stands today, is to a large extent the product of the interaction between colonial powers using "native administrations" to control and exploit colonial territory at a minimum administrative cost and collaborating elites and other local stakeholders. In his well-known study on the genesis of customary law in Zambia and Malawi, for instance, Chanock argues that customary law "was the cutting edge of colonialism, an instrument of the power of an alien state and part of the process of coercion", that was furthermore also shaped by power struggles within African communities adapting to the economic changes introduced by the capitalist economy of the colony. ${ }^{4}$

In particular, the institution and power of chiefs as the cornerstone of customary systems in Africa today, has been identified as a colonial construction. As Mamdani notes, "customary law consolidated the noncustomary power of chiefs." "Previously autonomous social domains like the household, age sets and gender associations... now fell in the domain of chiefly power", allowing chiefs to alter and instrumentalize customary laws to advance their interests over that of

\footnotetext{
3) See, e.g., Max Gluckmann, The Judical Process Among the Barotse of Northern Rhodesia (The Free Press, Gelncoe, IL, 1955).

4) Martin Chanock, Custom and Social Order, The Colonial Experience in Malawi and Zambia (Heinemann, London, 1998) 4. Cf., Terence Ranger, 'The Invention of Tradition in Colonial Africa', in E.J. Hobsbawm and T.O. Ranger (eds.), The Invention of Tradition (Cambridge University Press, Cambridge, 1983) 450-461; Francis Snyder, 'Colonialism and Legal Form: The Creation of "Customary Law" in Senegal' (1981) 19 Journal of Legal Pluralism and Unofficial Law 49-92.

5) Mahmood Mamdani, Citizen and Subject (Princeton University Press, Princeton, NJ, 1996) 110.
} 
women and youth." ${ }^{\prime 6}$ Other studies even branded the very notions of tribe, clan or other strict ethnic divisions within African societies as colonial inventions designed to serve divide and rule strategies. ${ }^{7}$ In recent years, the pendulum has gradually swung back with a number of scholars contesting the idea that presentday customary law and the identities it created are nothing but invented traditions without any precolonial roots. ${ }^{8}$

Political scientists and conflict resolution scholars have focused less on the historical authenticity of customary systems. Instead, they have taken greater interest in their efficacy in resolving conflict and enhancing social cohesion. Following the major political convulsions of the 1990s throughout the world, much of the academic literature focused on how weak, fragile or failed states could be strengthened, with the notion of State invariably referring to Max Weber's concept of a monolithic governance entity that claims a monopoly on the legitimate use of force within its territory. ${ }^{9}$ This thinking has also reverberated in the policy arena. For instance, the 2006 OECD Principles for Good International Engagement in Fragile States and Situations recommend a focus on state-building as the central objective, while defining the State in a Weberian sense as "the executive branch of the central and local governments within a state but also the legislative and the judiciary arms of government." 10

Meanwhile, an engagement with customary authority and law was disregarded. Rule of law activities focused on European-style courts and institutions, supported by the views of scholars who depicted customary law as the "modality of a primitive society" that would be extinguished by state law as "the instrument of civilization, of political society sanctioned by organized force, presumably above society at large, and buttressing a new set of social interests." ${ }^{11}$

In recent years, this approach has come under increasing criticism as neither being based an accurate description of the world outside the developed OECD member states, nor an appropriate prescription on how to improve governance and the rule of law in fragile contexts. Post-colonial state-building in particular

\footnotetext{
6) Ibid., at p. 110 .

7) Leroy Vail, The Creation of Tribalism in Southern Africa (University of California Press, Los Angeles, CA, 1989). See also David D. Laitin, "Hegemony and Religious Conflict: British Imperial Control and Political Cleavages in Yorubaland”, in: Peter B. Evans, Dietrich Rueschemeyer and Theda Skocpol (eds.), Bringing the State Back In (Cambridge University Press, New York, NY, 1985) 285-316.

8) See Thomas Spear, 'Neo-Traditionalism and the Limits of Invention in British Colonial Africa', (2003)

44 The Journal of African History 1 (2003), 3-27.

9) Max Weber, Politik als Beruf (Duncker \& Humblot, Munich/Leipzig, 1919).

10) The OECD Principles for Good International Engagement in Fragile States and Situations were formally endorsed by ministers and heads of agencies at the Development Assistance Committee's High Level Forum on 3-4 April 2007.

11) Stanley Diamond, 'The Rule of Law versus the Order of Custom', in Donald Black and Maureen Mileski (eds), The Social Organization of Law (Seminar Press, New York, NY, 1973), 318-343, at 318, 322-323.
} 
often resulted in the formation of nominally sovereign 'quasi-states' ${ }^{12}$ that de facto lacked the authority, capacity and socially perceived legitimacy to govern their territory and relied instead on customary institutions to complement or substitute for the lack of central state governance. Instead of customs being gradually but inevitably replaced by central state law, the reality on the ground is instead best described by the concept of legal pluralism, where two or more legal system exist side by side. ${ }^{13}$

With this reality in mind, Boege and others have sought to reconceptualize fragile states as "hybrid political orders" that "combine elements of the western model and elements stemming from the local precolonial autoecephalous traditions of governance and politics; governance is carried out by an ensemble of local, national and also often international actors and agencies." ${ }^{14}$ Doing so, they argue, would allow us "to identify and support processes of positive mutual accommodation between modern state institutions, customary local institutions and civil society institutions which might lead to the emergence of new forms of sustainable statehood." 15

Along the same lines, a major study recently published by the United States Institute of Peace on customary justice and the rule of law in post-conflict societies concludes that "customary justice systems must be treated as an enduring and influential component of the justice landscape as a whole and that policymakers and practitioners who ignore or seek to undermine them are doomed to fail." 16 Papers prepared for the World Bank, UNDP and the OECD's Development Assistance Committee in recent years have endorsed similar conclusions. ${ }^{17}$

While the efficacy of including customary institutions in post-conflict governance frameworks is increasingly being recognized, support for and proactive engagement with them is often still being opposed on grounds of their presumed

\footnotetext{
12) Robert Jackson, Quasi-states: Sovereignty, International Relations and the Third World (Cambridge University Press, Cambridge, 1990).

13) John Griffiths, 'What is Legal Pluralism?', (1986), 24 Journal of Legal Pluralism 1-55; Brian Z. Tamanaha, supra note 1.

14) Volker Boege, M. Anne Brown, Kevin P. Clemets and Anna Nolan. States Emerging from Hybrid Political Orders - Pacific Experiences (Australian Centre for Peace and Conflict Studies, Brisbane, QLD, 2008), $1-41$, at 5.

15) Ibid., at 9.

16) Deborah Isser, 'Conclusion: Understanding and Engaging Customary Justice Systems', in: D. Isser (ed.), Customary Law and Rule of Law in War-Torn Societies (U.S. Institute of Peace, Washington, DC, 2011), 325-368, at 325, 326.

17) See, e.g., OECD, Enhancing the Delivery of Justice and Security: Governance, Peace and Security (OECD, Paris, 2007); Leila Chirayath, Caroline Sage, and Michael Woolcock, Customary Law and Policy Reform: Engaging with the Plurality of Justice Systems (World Bank, Washington, DC, 2005), available online at http://siteresources.worldbank.org/ INTWDR2006/ Resources/ 477383-1118673432908/Customary Law and Policy Reform.pdf (accessed 1 May 2012); Ewa Wojkowska, "Doing Justice: How Informal Justice Systems Can Contribute," (UNDP Oslo Governance Centre, 2006), available online at http:// www.undp.org/oslocentre/ docs07/ DoingJusticeEwaWojkowska130307.pdf (accessed 1 May 2012).
} 
incompatibility with international human rights and rule of law standards. ${ }^{18}$ Even though customary law across the world is extremely diverse and one must be careful not to generalize too much, they have certain structural commonalities. On the one hand, customary systems offer local conflict resolution and justice mechanisms that are usually considered to be quicker, more affordable, geographically accessible, socially accountable and culturally appropriate by local communities.

On the other hand, customary systems may employ or condone particular practices and sanctions that are incompatible with the concept of human rights and the prohibition of cruel, degrading and inhumane punishment. More importantly, they tend to reflect the patriarchal social structures most of the world has traditionally abode by. With processes and decisions generally aiming at restoring social cohesion through consensus-making - rather than at upholding individual rights - they may reinforce existing power imbalances and marginalize women, youth and minority groups within the community. In addition, it is criticized that customary authorities are prone to corruption and favoritism, as they exercise unchecked power without formal democratic accountability mechanisms, rigid rules or a strict separation of powers (although this criticism neglects social checks and balances inherent to customary systems).

In multiethnic societies, the recognition of different customary laws and the accompanying identity-based systems of authority can also reinforce divisions, while recognition of only the dominant strains may force smaller ethnic groups to live by the cultural norms of others. In the African context, it has also been argued that the continued recognition of customary systems perpetuates the colonial-era discrimination between urban 'citizens' enjoying direct access to state institutions and rural 'subjects' living under 'decentralized despotism.' ${ }^{19}$ Others have taken issue with the generality of the 'citizen and subject' thesis, pointing out that chiefs often also end up defending the interests of the rural poor whose support ultimately sustain their own political position. ${ }^{20}$

There are serious potential human rights concerns that warrant a careful caseby-case assessment on whether and how to engage with customary systems. At the same time, it needs to be recalled customary systems are susceptible to change triggered from the outside, as their colonial era metamorphosis indicates. In principle, an assessment on whether to engage with an institution has to be based on an estimate how far the customary systems existing in a country can be reasonably expected to progress, not where it currently stands. Furthermore, it would be unfair to measure the customary systems against the benchmark of an idealized,

\footnotetext{
18) For a discussion of the shortcomings of customary system and a rebuttal, see Erica Harper, Customary Justice: From Program Design to Impact Evaluation (International Development Law Organization, Rome, 2011), 22-25.

19) Mamdani, supra note 4 .

20) Cherry Leonardi, 'Violence, Sacrifice and Chiefship in Central Equatoria, Southern Sudan', (2007) 77 Africa, 535-558, at 535, 537-539.
} 
fully human rights-compliant central state, because this ideal is removed from post-conflict realities. Instead, the benchmark of comparison have to be existing central state institutions in post-conflict countries, where external assistance partners also face the dilemma of either refusing to work with state institutions that remain de facto patriarchal, unaccountable and prone to endorse inhumane practices or work towards their reform with the risk of inadvertently lending legitimacy to an unacceptable status quo.

\section{Customary Law and the Genesis of South Sudanese Identity}

Customary law in South Sudan, is a symbol of emancipation from two centuries of external domination and, paradoxically, also the product of it.

External domination of Sudan as a whole began in 1821 with the Ottoman invasion of Northern Sudan, followed by an Ottoman-Egyptian administration and a brief period of northern Sudanese self-rule under the Mahdi movement. None of these regimes exercised permanent control over South Sudan, whose various ethnic groups governed themselves in accordance with their own customary laws. ${ }^{21}$ Only after the victory of General Kitchener over the Madhist forces in Omdurman in 1898, the United Kingdom and Egypt established a condominium of joint colonial rule over the entire Sudan. They administered North and South separately, initially with far greater focus on controlling and developing Northern Sudan. Control over the South was expanded from the 1920 through a policy of indirect rule developed by British imperial strategist Sir Alfred Milner. A 'Native Administration' to control and tax the colonial subjects at minimum administrative cost to the colonizers. For this purpose the colonial administration adopted the Chiefs Courts Ordinance in 1931, which set up a system of customary courts and authorities that continues to exist and has been reaffirmed by the 2009 Local Government Act. Moreover, chiefs were given executive functions. In this sense, it is not correct to distinguish between state courts and state officials on the one hand and non-state customary courts and chiefs on the other, as both sets of institutions have long been recognized by state law.

By the same token, the notions of "traditional law" and "traditional authority", which imply the legitimacy claims that customary law represents age-old traditions predating colonial conquest, should be used with a degree of circumspection. Like in other parts of Africa, indirect rule in South Sudan did not merely recognize the preexisting customary system, but distorted it to accommodate the exigencies of colonial rule. Notwithstanding the fact power structures differed widely between different ethnic groups - the Shilluk or the Azande had

${ }^{21)}$ Francis Deng, 'Customary Law in the Cross Fire of Sudan's War of Identities', in: D. Isser (ed.), Customary Law and Rule of Law in War-Torn Societies (U.S. Institute of Peace: Washington, DC, 2011), 285-324, at p. 287. 
constituted kingdoms, while many other ethnic groups like the Nuer were acephalous communities without hierarchical decision-making pyramids - the British introduced a pyramid of headmen, chiefs and paramount chiefs to serve their administrative needs. Chiefs were 'made' to fit this model and their courts were initially often perceived as colonial institutions in the eyes of the local population. $^{22}$

Upon Sudan's independence in 1956, the first civil war erupted between the Government of Sudan and the Anyanya movement initiated by Southern Sudanese military officers who rebelled against Northern oppression. Customary law and authority endured this conflict, although chiefs often found themselves caught between conflicting demands of allegiance from the Government and the insurgency. After a brief period of peace, the second armed conflict broke out in 1983, as a direct result of the Nimeiri regime's decision to impose Islamic Sharia Law on the entire country. The Sudan People's Liberation Movement/Army (SPLM/A), which was founded on the basis of a socialist ideology and sought the liberation of both North and the South to become one "New Sudan", in its initial discourse considered customary authority retrograde. ${ }^{23}$ Notably, the SPLM/A founding manifesto of 31 July 1983 makes no single reference to South Sudan's customary heritage.

However, in the face of policies of forced Arabization and Islamisation of the entire Sudan, fostered in the 1980s and 1990s by successive regimes in Khartoum, customary law and authority emerged as a pillar of resistance and counterforce to Sharia. Consequently, the SPLA/M shifted its stance and embraced it openly. At the first National Convention of the SPLM at Chukudum in 1994, chiefs were invited to participate and the SPLM committed itself to assign village government to customary authorities. The imposition of Islamic Sharia law from September 1983 on the entire Sudan, therefore, inadvertently strengthened the status of customary law. At the same time, the Sharia policy had much greater repercussions on state law, in that it marginalized, and often drove into exile, the class of legal professionals from North and South who had been educated in the Common Law. This leaves South Sudan without a corps of trained legal practitioners necessary to build a modern and professional legal system, yet again increasing reliance on customary authority to resolve conflict.

On the ground, the militarization of society resulting from the conflict often weakened the role of customary authorities. For one, it shifted power from tribal elders to younger men with guns. Declaring martial law in areas brought under

\footnotetext{
22) Manfred Hinz, Customary Law in Southern Sudan: A strategy to strengthen Southern Sudanese customary law as a source of law in an autonomous legal system (UNDP/Government of South Sudan, Juba, 2009). See also Douglas H. Johnson, 'Judicial Regulation and Administrative Control: Customary Law and the Nuer', 1898-1954, (1986) 27 The Journal of African History 59-78.

23) See also Markus V. Hohne, Traditional Authorities and Local Government in Southern Sudan (World Bank, Washington, DC, 2008) 17; Raphael K. Badal, Local Traditional Structures in Sudan (2006), 85.
} 
its control, the SPLA introduced its own governance structures to replace state institutions. In certain places, a duality of governance structures continues to exist. In 2008, for instance, the U.N. High Commissioner for Human Rights reported that the SPLA still operated a "Civilian Security" Service in Kurmuk (southern Blue Nile State, now North Sudan), which had been set up when the SPLA gained military control of the town in 1997 and rivals the authority of the local chief and the civilian police. ${ }^{24}$ Notwithstanding the SPLM/A commitment to local self-government, local commanders of the insurgency often appointed their own chiefs and in some cases even persecuted chiefs who resisted demands for supplies and recruits or were suspected of collaboration with the enemy. ${ }^{25}$

The war also brought with it massive population movements of both fighters and their families and displaced civilian populations, which weakened community bonds through which customary law is enforced. Today, a number of communities are torn by competing leadership claims between chiefs returning from displacement and those who took on these roles in their stead. ${ }^{26}$ Observers also note increasing interference by executive authorities at the county and (state) governor's level who seek to oust chiefs that have fallen out of their favor.

\section{The Constitutional Framework and the Reality on the Ground}

In the run-up to the Comprehensive Peace Agreement (CPA), concluded between the Government of Sudan and the SPLM/A in 2005, the Southern chief justice at the time, Ambrose Thiik, summed up a widespread sentiment in stating that customary law "embodies much of what we have fought for these past twenty years. It is self-evident that Customary Law will underpin our society, its legal institutions and laws in the future." ${ }^{27}$ Implementing this vision, the CPA stipulates that personal and family matters were to be governed by customary law and that all national legislation shall be based on 'popular consensus and the values and customs of the people of Sudan' ${ }^{28}$

\footnotetext{
24) High Commissioner for Human Rights, Eight Periodic Report on Sudan: Arbitrary Arrest and Detention Committed by the Police, Military and Intelligence Forces (OHCHR, New York, NY, 2008), 24.

25) See Cherry Leonardi, supra note 19, 544. Deng Biong Mijak, 'Traditional Authority in Post-Comprehensive Peace Agreement South Sudan,' in Manfred O. Hinz and Clever Mapaure (eds.), In search of Justice and Peace, Traditional and Informal Justice in Africa (Namibia Scientific Society, Windhoek, 2010).

26) Samson S. Wassara, Traditional Mechanisms of Conflict Resolution in Southern Sudan (Berghof Foundation for Peace Support, Berlin, 2007), 6. See also Sara Pantuliano, The land question: Sudan's peace nemesis (Overseas Development Institute, London, 2007).

27) Jok, Leitch and Vandewint, supra note 1, at p. 6.

28) Agreed Text on the Preamble, Principles and the Transition Process between the Government of the Republic of the Sudan and the Sudan People's Liberation Movement/Sudan People's Liberation Army, 2002 ('Machakos Protocol'), para. 3.2.3, available online at http://www.smallarmssurveysudan.org/pdfs/ HSBA-Docs-CPA-2.pdf (accessed 1 May 2012).
} 
The constitutional framework builds on the CPA, while seeking to balance between the political commitment and practical need to recognize customary law and authority on the one hand and the goal to establish a State with a central government and modern, democratic and effective institutions on the other. The Interim Constitution of Southern Sudan of 2005 and also the 2011 Transitional Constitution of the newly independent State of South Sudan recognize the customs and traditions of the people of Southern Sudan as a source of law and "traditional authority" as an institution at local government level on matters affecting local communities.

The 2009 Local Government Act implements these prescriptions. The hamlet level (boma) is to be the main domain of traditional authority, with customary justice institutions also operating up to the county level. Customary leaders and other influential community figures, including women, retain a formal channel to influence decision-making above the local level through Council of Traditional Leaders that are to be established at the state and national level. When this article was finalized, the state of Upper Nile had already set up a Council. Two others had passed legislation to that extent and all other states were working on legislation, while implementing legislation for the national level had not yet been adopted. In addition, the hierarchy of customary courts will continue to be formally recognized at the hamlet, district (payam) and county levels. However, their authority is limited to what state law would regard as civil disputes (family and marriages matters, etc.) and who operate under the authority of the relevant county's Customary Law Council. Appeals between the different layers of customary court and ultimately to state courts applying state law are envisaged.

The reality on the ground is much more complex than the neat division between the sphere of customary and formal state authority set out in the law. Most disputes will be settled by customary dispute resolution mechanisms in the larger family or community, without involving any state-sanctioned structures, whether state or chiefs courts. There is a strong expectation to only go to court, where mediation/arbitration by family or clan elders, spiritual leaders or other respected figures fails. ${ }^{29}$ Where formal courts and customary courts operate alongside each other, the population engages in "forum shopping" depending on the reputation of the court to hand down just decisions and also the relative cost, as both types of courts charge fees. ${ }^{30}$ At the same time, both state and chiefs court will engage in "norm shopping", borrowing from various types of statutes (including ones no longer officially in force) and customary precepts to justify their decisions. In the short run, the ambiguity and the resulting contest between the state and customary level force both systems to increase their responsiveness to social needs and

\footnotetext{
29) Deng, supra note 20, 295.

30) Cherry Leonardi, Leben Nelson Moro, Martina Santschi and Deborah H. Isser, Local Justice in South Sudan (Rift Valley Institute/United States Institute of Peace, Nakuru, 2010), 48.
} 
allows the population to avoid local justice forums that are corrupt, ineffective or unjust in their results. In the long run, however, the rule of law will not be built without legal certainty about the applicable law, clear division of authority and lines of appeal. In particular, long-standing disputes over land, exacerbated by successive waves of displacement, cannot be handled without a clear designation of responsibilities.

In the contest of courts, the chiefs are often regarded as preferable in the eyes of the local population since they operate on the basis of culturally understood processes. Customary law dispensed by customary authorities is a process aimed at identifying and balancing interests within the community, rather than enforcing hard rigid rules. Customary law thereby provides a formalized framework for negotiations and conciliation, where rules are used mainly as a point of departure. Some ethnic groups have established specific institutions to balance differentials of power and nudge the parties to a conclusion.

For instance, in the customary courts of the Dinka (South Sudan's largest ethnic group), there will be a man called the Agemlong, whose task it is to repeat and summarize the parties' positions in a raised voice, thus physically ensuring that every participant is equally heard. Deliberations will often take hours and hours until the court reaches a position to make a decision that will carry the consensus of the community and can thereby be enforced. Belief in supernatural sanctions based on oaths and rituals administered by spiritual leaders (known as spearmasters in Dinka and Nuer culture) provides further enforcement pressure. In the eyes of the local population this process is preferable to the state courts that apply rigid rules, which cannot be read by the largely illiterate population, and makes judges appear to only "look at their books of laws or case papers, not at the litigants in front of them." ${ }^{11}$

The lack of understanding about state law and process among the general population, along with suspicions deriving from procedural delays and adjournments, also drive a widespread perception that corruption and favoritism is rifer in state courts. In reality, observers have seen such problems in both the regular and the customary courts, as both often reflect the interests of dominant power structures, in particular if the case concerns influential figures from the military or political establishments. ${ }^{32}$ Yet, customary courts are subject to social accountability mechanisms. Chiefs still most often hold a hereditary position and are chosen by public acclamation carefully prepared by the elders, rather than contested elections. However, there will usually be several eligible candidates in the male line of the Chief's family, allowing communities to oust incumbents who have lost their trust and replace them with better candidates.

\footnotetext{
31) Ibid., 36.

32) Ibid., at 39-41.
} 
According to the Local Governance Act, customary courts must not deal with criminal cases, except for cases with a "customary interface" referred to them by state courts. From the perspective of customary law, almost every case has of course a customary interface. Moreover, the very distinction between civil and criminal cases does not make sense from the customary system's point of view, as customary law aims to resolve social disputes in all their dimensions with a view to reestablishing community cohesion..$^{33}$ Emphasis will be placed on restorative justice, the payment of compensation in money or cattle, whereas punishment is often reserved for those who appear incorrigible or outside the bounds of the community consensus. Although this is not foreseen by the 2009 Local Government Act, the chiefs court still rely on preexisting rights to call on the regular police to enforce their decisions, even where they involve sanctions such as temporary imprisonment or whipping. Moreover, there is persistent demand by chiefs to be formally assigned police to work at their orders.

Increasingly, the central State challenges chiefs who continue dealing with more serious criminal matters and there is a widespread understanding that cases involving serious violence, namely homicide cases, are to be brought to the state authorities. There is also an increasing tendency for the local population to take cases involving abuse of power by public officials or the military to the formal courts and the police, in the hope that they have a greater chance of enforcing justice over power.

However, in remote rural areas even the most serious cases will often still be dealt with by the customary system. This is also a reflection of the fact that state courts are not geographically accessible in a country that is twice the size of France and has hardly any paved roads navigable during the long rainy season. It is estimated that even with all positions filled - and there are not enough qualified South Sudanese legal professionals willing to serve in remote rural areas - the coverage of state judges per citizen is less than 10 percent of what it should be. ${ }^{34}$

Customary law can take on conflicts between people from different ethnicities provided they both recognize the customary authorities making the decision, which also depends on the type of case at hand (land and grazing grounds being a particularly sensitive and vital issue between ethnic groups). Many key principles are shared by Sudan's more than fifty different ethnic groups and differences tend to reflect economic realities rather than principles. Compensation awards, for instance, tend to be higher among the richer pastoralist tribes than in sedentary farming communities.

Due to traditions of blood feud, there is a strong causal relationship between local justice failure and deadly inter-clan and interethnic clashes, which are often

\footnotetext{
33) J. Wuol Makec, The Customary Law of the Dinka People of Sudan (Afro World Publishing, London, $1988)$ at 37.

34) David Pimentel, Rule of Law Reform Without Cultural Imperialism? Reinforcing Customary Justice through Collateral Review in South Sudan' (2010) 2 Hague J. on the Rule of Law, 1-28, at 1, 16.
} 
exacerbated by the proliferation of small arms and the political manipulation of identity rifts. Instead of customary authorities driving such conflicts, the State will often rely on customary authorities to broker peace after inter-clan and tribal clashes. Customary leader gathered at the Wunlit Conference in 1999, for instance, were instrumental in reconciling ethnically based factions of the SPLM/A, which had been fighting a brutal war against each other and civilian populations affiliated to them. Often maligned as a source of ethnic division, customary law and authority is therefore also a key aspect of managing ethnic diversity in rural South Sudan.

Conversely, in more urban areas, chiefs and elders increasingly have trouble asserting their power over returning refugees and internally displaced persons who lived long years in contexts, where the state (or international aid agencies) had greater roles in settling disputes. This trend is going to accelerate with independence, as the more than two million Southern Sudanese who were displaced to Khartoum and other cities in the North during the war find themselves under increasing pressure to return to the South. One very visible group outside the bounds of customary law and authority are youth returning from displacement abroad who adopted the dress code and demeanor of African-American street culture. ${ }^{35}$ Disputes also result from the need to integrate distinguished fighters who would like to be rewarded for the hardship they endured, while also giving space to returnees and the technical expertise they bring with them.

\section{South Sudan's Customary Laws and Human Rights}

The relationship between customary law and human rights considerations is complex and has important historical antecedents. Prior to Sudan's independence, the colonial administrators had the right to set aside customary laws and rulings if they were "repugnant to justice, morality or order". These repugnancy clauses, used in systems of indirect rule across British colonial Africa, reflected on the one hand the interests of colonial control and on the other also Victorian "humanitarian" sensibilities. ${ }^{36}$ For the local population, interference through the repugnancy clause was deeply offensive, as they naturally considered their own custom to be the very reflection of justice, morality and order. This colonial legacy has

\footnotetext{
35) In ignorance of Sudan's own tragic history of slavery and racial discrimination, these youth are often referred to as "niggers" by the resident population and sometimes even in the official discourse, One infamous ordinance adopted in 2008 by local authorities in the capital Juba (Commissioner's Local Order No. 4. 2008) explicitly outlawed "nigger behavior" and led to the arrest of young women and men on the basis of their choice of dress until the ordinance was revoked after the central government intervened. In mobilizing against the arrests, the SPLM Deputy Secretary-General depicted the arrests as being based on defunct Sharia law, thereby effectively mobilizing public sentiment against violations committed in the name of upholding tradition.

36) Mamdani, supra note 4, at pp. 115-116.
} 
repercussions for efforts today to reform aspects of customary law that are not in line with international standards. On the one hand, there is great openness to human rights as anathema to the oppression and discrimination experienced during the conflict, as also reflected in the prominent role of human rights in the constitution. On the other hand, local communities will often still perceive universal human rights standards as an external imposition and threat to South Sudanese identity where they clash with customary law precepts.

In several regards the customary law system is at odds with international human rights standards, in particular where it takes on criminal justice matters. The customary system's record in the criminal justice arena is checkered. Its focus on restorative justice will often save perpetrators of less serious crimes from the inhumane reality of South Sudan's current penitentiary system or corporal punishment (which is also ordered by state courts). On the other hand, it can result in impunity for serious offenses, in particular sexual violence. In cases of rape, the customary authorities will often focus on arranging some kind of compensation and reconciliation agreement between families.

Customary authorities (and sometimes also other local authorities) will also entertain cases involving allegations of witchcraft. Beliefs of witchcraft are still deeply entrenched in Southern Sudanese society and supernatural causes are often invoked to explain deaths and illnesses that otherwise appear inexplicably to the community in the absence of adequate medical care and public education. In dealing with such cases, more enlightened chiefs will try to protect the accused who often hold a marginalized place in the community, and broker some kind of resolution, sometimes relying on their spiritual powers to undo the bewitchment. However, there are also many documented cases, in which suspected "witches" were killed or otherwise punished at the behest of customary authorities.

The gap between customary law and international human rights law is most obvious with regard to the position of women. South Sudan's ethnic groups are generally patrilineal, polygamous and patriarchal in their social structure. Great importance is attached to a man passing on his name to a large number of children. If a man wishes to get married, his family has to pay bride wealth to the woman's family. The sums involved are often enormous, especially among the pastoralist tribes, where a marriage can involve the transfer of a hundred heads of cattle between families. As a result, women's reproductive capacity is a valuable asset and tightly controlled. Under the customary law, women are not free to choose to live with a man incapable or unwilling to pay bride wealth and children born from such a relationship will be placed under the custody of the maternal uncle. Married women find themselves under intense pressure not to divorce as this would trigger a claim to restitute the bride wealth.

Moreover, in case of divorce, custody will almost invariably be granted to the man. Several ethnic groups also practice levirate marriage: in case of death of the husband, another male relative from the patrilineal line will 'inherit' the wife. 
When women or girls resist such practices and turn to the state or international actors for help, the results can often deeply disruptive and bear the potential for feuds and larger conflict, as solutions upholding women's rights are usually hard to reconcile with the social and economic interests of the larger family clans involved. Sustainable strategies should, therefore, look at ways to reform customary rules so as to reconcile both community interests and individual rights. If for instance, women who were subject to domestic violence could divorce without the women's family having to return bride wealth, this would provide a powerful economic incentive to stop abusive husbands.

Divorced women, widows and female descendants in particular also lack equal access to land and inheritance rights under the customary system. In this sensitive area, the South Sudan Land Commission's draft Land Policy, presented in February 2011 to the Government, pledges to promulgate marriage, inheritance, and related laws to ensure recognition of the equal rights of those women who may not enjoy equal rights under various provisions of customary law and practice. ${ }^{37}$

\section{Conclusion and Outlook: The Future of the Customary System}

The future of customary authority in South Sudan has been the subject of an intense debate. The spectrum of opinion ranges from modernists who see its existence as a necessary, but temporary evil and traditionalists who want to strengthen customary law and authority for its own sake.

Consistent with the constitutional provisions, the Government has been promoting a strong role for customary law. The Ministry of Justice (the former Southern Sudan Ministry of Legal Affairs and Constitutional Development) is taking the lead, while responsibility for U.N. support to the customary system rests with the United Nations Development Programme (UNDP).

The Government and UNDP have jointly developed a customary law strategy to strengthen customary law as a source of law in an autonomous legal system. ${ }^{38}$ Although it has yet to be formally adopted by the Government, as of writing, policy initiatives have been developed in line with its basic tenets: (1) ascertaining the status quo of customary law, (2) fostering its change and development in line with international standards, (3) developing the legal and social environment for its operation, (4) supporting research on customary law and (5) coordination. For the latter two purposes, the Ministry of Justice and UNDP have prioritized the establishment of a Centre for Customary Law in Rumbek (a town widely seen as

\footnotetext{
37) Southern Sudan Land Commission, Draft Land Policy (Government of South Sudan, Juba, 2011), p. 16, also available online at http://www.scribd.com/doc/49322360/Draft-Land-Policy\#open download (accessed 1 May 2012).

38) See supra note 21.
} 
the heart of traditional Dinka culture) that has been built, although its functions and powers have yet to be agreed upon and formalized by legislation.

A number of influential decision- and opinion-makers have strongly focused on ascertaining and writing down what the customary law is, so that it can be applied in a uniform fashion and is also accessible to state judges, especially if they are posted in a place with different customs than those of their home region. Alongside the Ministry of Justice, the current Chief Justice, author of a wellknown restatement of Dinka customary laws, has been a driving force. The outright codification of customary law is problematic because the law becomes petrified and can no longer reflect changing values, especially with regard to human rights and gender equality. Experience from colonial codification efforts also shows that the supposed experts on the law, namely the chiefs and elders themselves, will naturally foster their own interests at the expense of women and youth. ${ }^{39}$ Codification also changes the nature of customary law itself, as a process of balancing interests in line with general principles is replaced by rigid rules. Moreover, there is a risk of instrumentalising the claim of codifying custom for extraneous purposes. The adoption of the Lakes State Customary Act in 2010, with very little consultation, provides a warning in this respect. Essentially a criminal statute, the Act provides harsh penalties up to the death penalty (e.g. for killing an "educated or civilized person") for offenses that should be covered by South Sudan national legislation. Moreover, it criminalizes and penalizes with prison administrative failings (e.g. burying bodies outside designated areas).

In trying to balance between these concerns and the perceived needs, the Customary Law Strategy foresees an inclusive process that allows communities to ascertain their own customary laws, rather than opting for outright codifications. In practice, the result might prove to be the same, as the ascertained law might guide courts applying the customary law and could also provide a blueprint for codifications.

UNDP has started ascertainment in the East of South Sudan, focusing on smaller ethnic communities, whose customary laws have been less well documented. It has set an ambitious schedule of ascertaining the law of 20 ethnic groups in four months. As a result, it will not be possible to fully implement the complex, but inclusive ten step self-ascertainment model, foreseen by the Customary Law Strategy. This bears the risk that customary leaders will use their role as "custodians of customary law" that the Customary Law Strategy envisages them to have ${ }^{40}$ to shape the ascertained law once again in their favor to the detriment of women, youth and minority groups within the community. A better alternative would be to draw out the ascertainment process and use it to initiate a genuine and inclusive discussion within the community on where customary

\footnotetext{
39) Ranger, supra note 3, 250; Chanock supra note 3. See also Harper, supra note 17, at 43-44.

40) See Hinz, supra note 21.
} 
law should go under the new constitutional order, in particular providing space to women, youth and minority groups to articulate their vision. This would also allow more closely tying the ascertainment process to trainings for chiefs on the constitutional framework that UNDP is organizing.

Concerning the key question on how customary leaders are to be selected and held accountable in a democratic state, the Government is making careful efforts to integrate chiefs into formalized government structures. The Local Government Act stipulates on the one hand that chiefs are to be 'elected according to conventional electoral system or selected according to traditional practices as the case may be'. On the other hand, however, they have to be selected by a committee headed by state judge in order to serve as judges in chief courts. Elections among chiefs or by the communities will determine membership in the Council of Traditional Leaders at the state and national level.

At the same time, the Government has made moves to gradually wrestle control over land administration from traditional authorities. The draft Land Policy ${ }^{41}$ proposes that the administration of land is handled by County Land Authorities and Payam Land Councils. Chiefs would be allowed to serve on the Councils but the trusteeship and administrative responsibilities would be legally vested in the Council and not in the chiefs themselves. This tenet of the Land Policy forms part of a larger attempt to tie chiefs to formalized state structures, including in the context of the Local Governance Act and the Councils on Traditional Leaders.

The challenge in implementing these models in practice will be to ensure that the accountability of chiefs is promoted, while preventing them to be coopted by executive power, especially as chiefs can provide a voice to rural communities and potentially pose an important and moderating counterweight to autocratic centralization tendencies (reinforced by the ongoing political and military tension with (northern) Sudan) and to the countervailing efforts of local political figures to mobilize and militarize their communities along ethnic lines.

41) See supra note 36. 